\title{
Assessment knowledge of female academic staff in Kirkuk- Technical Institute to tetanus toxiod vaccination Wafa Mahmood Jasim $(\mathrm{PhD})^{1}$ Abstract
}

Background:Tetanus is a preventable disease and no age is immune unless there is a previous protection with tetanus toxiod immunization which is a highly effective and the immunity lasts several years.

Objective: To assess the female academic staff knowledge regarding the vaccination status with tetanus toxoid.

Patients and Methods: A cross- sectional study was conducted in Kirkuk Technical Institute for the period from 1st January /2014 till the end of May 2014. A randomly selected sample from different scientific departments and a special questionnaire form was prepared by direct interviewing with the study sample and 100 female academic staff were participated in the study after receiving a verbal consent from them before establishing the study.

Results: The results revealed that $43.0 \%$ of study female academic staff aged ( 41-50) years , (53.0\%) having a master certificate , (61.0\%) of them are assistant lecturers , and (81.3\%) of study female staff were vaccinated with tetanus toxiod , and $73.6 \%$ of them are completed their vaccination schedule with tetanus toxiod during their reproductive life.

Conclusion: The study concluded that female staff who are not completed their vaccination status with tetanus toxiod because of over load working.

Key words: Vaccination, women,Tetanus toxiod, Kirkuk.

Corresponding Author: Wafamahmod396@yahoo.com.

Received: $24^{\text {th }}$ September 2017

Accepted: $14^{\text {th }}$ November 2017

https://doi.org/10.26505/DJM.

\section{${ }^{1}$ Community health dept-Kirkuk Technical Institut - Kirkuk - Iraq.}

\section{Introduction}

Tetanus is one of the life-threatening disease which caused by the bacterium Clostridium tetani that enters to the body through an abrasion wound, and it has been referred as the "inexcusable disease" because of its serious and completely preventable nature[1]. Tetanus is a very highly dangerous fatal disease with a mortality rate about $35 \%$, and a proximal (309000) deaths occurs due to maternal or neonatal tetanus which reflect a triple failure of public health because of defect in routine immunization program during pregnancy period, poor ante- natal care 
health services, increase home delivery, and unhygienic delivery condition $[2,3]$ , therefore many women die every year due to maternal tetanus that is responsible for more than $5 \%$ of maternal deaths and 30,000 women affected by the tetanus disease[4].

In the recent years, there was a high decline in tetanus disease occurrence because of the widely coverage of immunization program with (Tetanus Toxiod)TT vaccine and WHO recommended that administration of single TT vaccine is not enough to protect the women from Tetanus disease, so the women need more than two doses of vaccine (TT1, TT2) in order to receive a sufficient immunity through out their life [5].

The protection from Tetanus disease started 15days after the 2nd dose of TT vaccine and it should be complete the recommended 5 doses of it through a regular interval schedule to maintain the essential provided protection[6].

Tetanus Toxiod (TT) is usually given to the reproductive women at the age between (15-44) years in order to protect both of ( mother from Tetanus disease ) and ( New born infant from Tetanus Neonatorum which is regarded as a fatal disease caused by a bacterial infection due to unhealthy condition ) $[7,8]$, and for that reason Tetanus vaccine is the only preventable one against Clostridium bacteria which is mainly found in the human gut, domestic animals and soil[9].
The evaluation of a patient's immune response and mechanism to certain vaccinations like (TT) serves as a relation to his/her ability to fight natural infections and it is necessary in the assessment of the humeral immune system., so the clinical indications and guide lines for assessing and evaluating vaccine responsiveness include many items like (frequent and recurrent Sino pulmonary or otic infections, chronic gastrointestinal infections, any severe or unusual infections, and abnormal need for antibiotics)[10, 11].

The study aimed to assess the teachers knowledge regarding the vaccination status with tetanus toxiod vaccine.

\section{Patients and Methods}

\section{A- Study subjects}

Official permission was taken from / Kirkuk Technical Institute / and a verbal consent was taken from each women before establishing the study . A crosssectional study was carried out in Kirkuk Technical Institute and a randomly selected sample of 100 teachers from different scientific depts.

A special questionnaire form was conducted after receiving their agreements to participate in the study. The study was done during the period from $1 \mathrm{st}$ January /2014 till the end of May 2014. The participant teachers were ensured confidentially that this questionnaire form was for research purposes only and allow them to be free with drawl from the study at any time they want. 


\section{B- Study methods}

The data was collected by direct interviewing them and full explanation of the study aim was done by the investigator, then full case history about the vaccination status with tetanus toxiod (TT) during their pregnancies with the help of vaccine cards which was received from the primary health care centers during their attendance to them .

The prepared questionnaire form contained 5items about the TT vaccine which are:

Part-1- Demographic characteristics including (age, certificate ,scientific degree, marital status ).

Part-2- Teachers vaccination status .

Part-3- Teachers knowledge regarding the tetanus toxiod vaccine.

Part-4-Teachers future suggestions regarding vaccination program.

Part -5-Teachers distribution about the causes for not completed their vaccination.

The last overall final question which is: "Are you received a 5 doses of TT vaccine through your attendance to primary health center (PHC) ?" had an answer of "Yes" or "No" only.

\section{Statistical Analysis}

The data was statistically analyzed by using descriptive statistics for questions with yes and no answer .

The items of teachers knowledge were rated according to type of likert scale as(yes- uncertain-no ) and scored as [12]:

3 for yes answer

2 for uncertain answer

1 for no answer

Cut off point $(3+2+1) / 3=2.0$, so the results calculated by using the following formula :

No. of teacher said yes $\times 3+$ No. of teacher said uncertain $\times 2+$ No. of teacher said no $\times 1 /$ Sample size (100)

\section{Results}

Table(1)shows that majority of study women aged between 41-50 years $(43.0 \%)$, with a Master certificate $(53.0 \%)$ , assistant lecturers $(61.0 \%)$, and they are married $(91.0 \%)$. 
Table (1): Socio demographic characteristics of the study sample.

\begin{tabular}{|c|c|c|c|}
\hline \multirow{2}{*}{\multicolumn{2}{|c|}{ Socio- demographic parameter }} & \multicolumn{2}{|c|}{$\begin{array}{c}\text { Study teachers } \\
\mathrm{N}=100\end{array}$} \\
\hline & & No, & $\%$ \\
\hline $\begin{array}{l}\text { Age Group } \\
\text { (years ) }\end{array}$ & $\begin{array}{c}<30 \text { years } \\
31-40 \text { years } \\
41-50 \text { years } \\
51-60 \text { years } \\
>60 \text { years }\end{array}$ & $\begin{array}{c}12 \\
21 \\
43 \\
15 \\
2 \\
\end{array}$ & $\begin{array}{c}19.0 \\
21.0 \\
43.0 \\
15.0 \\
2.0 \\
\end{array}$ \\
\hline Certificate & $\begin{array}{c}\text { PhD } \\
\text { Master } \\
\text { Diploma } \\
\text { Bachelors } \\
\end{array}$ & $\begin{array}{c}7 \\
53 \\
8 \\
32 \\
\end{array}$ & $\begin{array}{c}7.0 \\
53.0 \\
8.0 \\
32.0 \\
\end{array}$ \\
\hline Scientific degree & $\begin{array}{l}\text { Assistant proof } \\
\text { Lecturer } \\
\text { Assistant lecturer }\end{array}$ & $\begin{array}{c}2 \\
37 \\
61\end{array}$ & $\begin{array}{c}2.0 \\
37.0 \\
61.0\end{array}$ \\
\hline Marital status & $\begin{array}{c}\text { Married } \\
\text { Unmarried }\end{array}$ & $\begin{array}{c}91 \\
9\end{array}$ & $\begin{array}{c}91.0 \\
9.0\end{array}$ \\
\hline
\end{tabular}

* un married women were excluded from the study

Regarding the vaccination status, the results show that most of teachers were vaccinatedwith tetanus toxiod $(81.3 \%)$, and $(18.7 \%)$ of them were not vaccinated as in table.

Table (2): Frequency distribution of study teacher sample according to their vaccination status with tetanus toxoid.

\begin{tabular}{|c||c|c||}
\hline \multirow{2}{*}{\multicolumn{1}{|c|}{}} & \multicolumn{2}{c|}{} \\
\multirow{2}{*}{ Vaccination status with tetanus toxiod } & \multicolumn{2}{c|}{ No91 } \\
\cline { 2 - 3 } & No. & $\%$ \\
\hline \hline Vaccinated & 74 & 81.3 \\
\hline \hline Not vaccinated & 17 & 18.7 \\
\hline \hline Total & 91 & $100.0 \%$ \\
\hline
\end{tabular}

Majority of teachers have a grand mean knowledge index above 2.0 regarding the importance of tetanus toxiod vaccine [2.1] and its doses [2.02] while it is below [2.0] for vaccination time and last dose of it [1.9] as in table(3). 
Assessment knowledge of female academic staff in Kirkuk- Technical Institute to tetanus toxiod vaccination

Wafa Mahmood Jasim

Table (3): Distribution of female teachers according to their knowledge index regarding the tetanus toxiod vaccination.

\begin{tabular}{|c|c|c|c|c|c|}
\hline \multirow[b]{2}{*}{ Knowledge parameter } & \multicolumn{3}{|c|}{ Teachers number $=50$} & \multirow[b]{2}{*}{$\begin{array}{c}\text { Mean of } \\
\text { score }\end{array}$} & \multirow[b]{2}{*}{$\begin{array}{c}\text { Crand mean } \\
(\mathrm{CM}) / \text { assessment } \\
\text { value }\end{array}$} \\
\hline & Yes & uncertain & No & & \\
\hline $\begin{array}{l}\text { Importance of Tetanus toxoid vaccination } \\
\text { a- Prevention of tetanus disease in pregnant } \\
\text { women only . } \\
\text { b- Prevention of tetanus disease in child only } \\
\text { c- Prevention of tetanus disease in both of them }\end{array}$ & $\begin{array}{l}13 \\
27 \\
41 \\
\end{array}$ & $\begin{array}{l}42 \\
18 \\
10 \\
\end{array}$ & $\begin{array}{l}29 \\
23 \\
\end{array}$ & $\begin{array}{l}2.4 \\
1.9 \\
2.2\end{array}$ & $\begin{array}{c}\mathrm{GM}=2.1 \\
\text { Above cut- off } \\
\text { point }\end{array}$ \\
\hline $\begin{array}{l}\text { Vaccination time } \\
\text { a-One single dose during pregnancy period } \\
\text { b-Two doses through out the pregnancy with } \\
\text { one booster dose after delivery } \\
\text { c- Two doses during pregnancy with booster } \\
\text { dose through } 5 \text { years period }\end{array}$ & $\begin{array}{l}15 \\
30 \\
21\end{array}$ & $\begin{array}{l}39 \\
21 \\
17\end{array}$ & $\begin{array}{l}20 \\
23 \\
36\end{array}$ & $\begin{array}{l}1.9 \\
2.1 \\
1.7\end{array}$ & $\begin{array}{c}\mathrm{GM}=1.9 \\
\text { Below cut-off } \\
\text { point }\end{array}$ \\
\hline $\begin{array}{l}\text { Vaccination doses } \\
\text { a- Single dose } \\
\text { b-Two doses }+ \text { one dose later } \\
\text { c- Two doses }+2 \text { doses later } \\
\text { d- } 5 \text { recommended doses } \\
\end{array}$ & $\begin{array}{l}24 \\
17 \\
36 \\
43 \\
\end{array}$ & $\begin{array}{l}20 \\
28 \\
14 \\
14 \\
\end{array}$ & $\begin{array}{l}30 \\
29 \\
24 \\
17 \\
\end{array}$ & $\begin{array}{l}1.9 \\
1.8 \\
2.1 \\
2.3 \\
\end{array}$ & $\begin{array}{c}\mathrm{GM}=2.02 \\
\text { Below cut- off } \\
\text { point }\end{array}$ \\
\hline $\begin{array}{l}\text { Last doses of vaccination } \\
\text { A-Beforeone month of delivery } \\
\text { B-Before two months of delivery } \\
\text { c-Before three months of delivery }\end{array}$ & $\begin{array}{c}7 \\
27 \\
45\end{array}$ & $\begin{array}{l}40 \\
18 \\
12\end{array}$ & $\begin{array}{l}27 \\
29 \\
17\end{array}$ & $\begin{array}{l}1.7 \\
1.9 \\
2.3\end{array}$ & $\begin{array}{c}\mathrm{GM}=1.9 \\
\begin{array}{c}\text { Above cut- off } \\
\text { point }\end{array}\end{array}$ \\
\hline
\end{tabular}

Table (4): Distribution of female teachers according to their complete status of tetanus toxoid Vaccination.

\begin{tabular}{|c|c|c|}
\hline \multirow[t]{2}{*}{ The reasons for not completing TT vaccine } & \multicolumn{2}{|c|}{$\begin{array}{l}\text { Study teachers } \\
\text { (Not completed ) } \\
\mathrm{N}=24\end{array}$} \\
\hline & No. & $\%$ \\
\hline Long time needed to reach the PHCC & 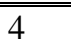 & 16.7 \\
\hline Vaccine usually not found in the PHCC & 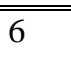 & 25.0 \\
\hline No encouragement from husband & 3 & \\
\hline Lack of motivation & 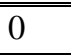 & 0.0 \\
\hline Fear of vaccination side reaction & 2 & \\
\hline Over load working & 9 & 37.5 \\
\hline Total & 24 & $100.0 \%$ \\
\hline
\end{tabular}


Assessment knowledge of female academic staff in Kirkuk- Technical Institute to tetanus toxiod vaccination

Wafa Mahmood Jasim

$37.5 \%$ of study teachers were not

tetanus toxiod because of over load completed their vaccination status with working.

Table (5): Distribution of female teachers according to their reason for not completing tetanus toxoid vaccination.

\begin{tabular}{|c|c|c|}
\hline \multirow[t]{2}{*}{ Validity of TT vaccine } & \multicolumn{2}{|c|}{$\begin{array}{c}\text { Study teachers } \\
\text { (Completed ) } \\
\quad \mathrm{N}=67\end{array}$} \\
\hline & No. & $\%$ \\
\hline Valid vaccination & 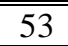 & 79.1 \\
\hline Crude vaccination & 14 & 20.9 \\
\hline Total & & $100.0 \%$ \\
\hline
\end{tabular}

*Valid vaccination $=$ any women receive 5 doses of TT vaccine at recommended schedule.

$*$ Crude vaccination $=$ any women receive 5 doses of TT vaccine at different interval.

Table (5) reveal that $79.1 \%$ of the study teachers were completed their valid vaccination status during their life.

\section{Discussion}

The current study show that majority of study teachers were vaccinated with tetanus toxiod during their reproductive life . A study was conducted by Siddigi etal / 2007 [13] in Pakistan to assess the coverage of expanded program of immunization and they found that most of study women were not vaccinated with the tetanus vaccine because of the difficulty and unavailability of it in the primary health care center during their visiting.

A similar study was done by Mohammed etal / 2010 [14] in Peshawar / Pakistan to verify the coverage rate of TT vaccination and assess the main factors related to it among women in the reproductive age groups between (17-45) years . They mentioned in this study that $55.6 \%$ of the study sample were completed their vaccination with $\mathrm{TT}$ and $22.4 \%$ were vaccinated incompletely, and $22.0 \%$ of them were never taken any dose of vaccine at all .

Regarding the knowledge of teachers towards the TT vaccine, the present study show that most of them having a high grand mean knowledge index regarding the value of TT vaccination and its doses.

A study was conducted by Islam etal / 2009[15] in Bangladesh / Dhaka District / BoroChandrial village among 224 women at reproductive age between (15-49) years to determine the TT vaccination coverage in a rural area. They reported in their study that main causes for TT vaccination decline due to 1- lack of educational back ground about the necessity of the vaccine during their life (54.4\%) 2- un awareness of completing the $2 \mathrm{nd}$ and $3 \mathrm{~d}$ doses of it $(48.5 \%)$. Further more they reveled that their knowledge about the benefits of TT was very fair for both the mother and child and there was a clear defect in the attitude of the study sample regarding the value of 
vaccination for them. Concerning the complete status of TT vaccine, the present study show that more than two third of the study women completed their vaccination schedule with tetanus toxoid. Rahman / [16] preformed a similar study in Bangladesh /2009 to assess the utilization and coverage of TT among reproductive women . He found in his study that there was a significant decline in the immunization coverage among them because of their husband had a low educational level. In addition to, there was a statistically relation between the women knowledge and TT vaccination and complete status of it.

Another study was conducted by Afridi etal / [17]2005 in Peshawar among female of reproductive age to assess the main factors associated with the immunization coverage with TT vaccine. They found that the women who are not vaccinated because of low educational level and unawareness of vaccination importance during their life .

WHO [18] estimated that the TT2 vaccination was $55 \%$ and this variable results related to demographic changes in Pakistan . A similar study was prepared by Mohammad etal / [19] 2014 in AlShatrha district / Al-Shatrha PHCC/Iraq among reproductive attendant women aged between (15-45) years . They found that most of studied women were not completing the vaccination status and $73.3 \%$ of them were vaccinated while $24 \%$ were not vaccinated .

Another study was prepared by Hasnain etal / 2007[20] in Lahore district to determine the main reasons behind the low coverage of TT vaccination among pregnant women and they reported that most of study women were not complete their recommended schedule and the coverage rate of immunization program was $(87 \%)$. They documented in their study that both of the health care provider and public health system should maintain the acceptance and delivery of the recommended vaccination.

Regarding the main causes for not completing the TT vaccination were overload working issues and the vaccine usually not found in the PHC. Inakci etal / 2009 [21] mentioned in their study in Sanliurfa to assess the coverage of TT vaccination that the main reason behind low immunization coverage are lack of awareness between the mother, and family income which has an important role in decreasing the immunization level and lastly the far distance between the health care center and their home which unable them to reach it.

Same results were obtained from Nisar etal [22] /in Pakistan / Karachi to evaluate the knowledge, attitude of women towards TT vaccination and they found that the main causes behind that were the lack of motivation too attended the PHCC and too much time needed to reach it because of the far away distance between their homes and it Concerning the validity of vaccination status with TT vaccine, the current study show that most of teachers having a valid vaccination and complete 5 doses of the recommended schedule. 
A study was prepared by Khan etal / [ 23] 2009 in Dhaka district to assess the coverage rate of immunization with TT vaccine and its validity among reproductive women and they found that the proportion of invalid vaccination was $6.2 \%$ for TT2, and for TT3 doses was $7.3 \%$, for TT4 was $12.5 \%$ and the lowest value for TT5 is $10.8 \%$, and $55.6 \%$ for over all decrease in the TT doses from TT1- TT5 and they explained this defect due to unawareness of women towards the necessity of vaccination during their reproductive life and lack of motivation to complete the remaining doses of the recommended schedule . Another possible cause that this variation in results appear due to different study places which affected directly the out comes.

\section{Conclusions}

1-There was a good knowledge index regarding the importance of TT vaccination and its doses.

2-Study teachers were completed their vaccination schedule with TT during their life.

3- The main causes for not completing the recommended doses was of over load working.

4- Most of teachers having a valid status with TT vaccine.

\section{Recommendations}

Further educational programs concentrated upon the importance of TT vaccination schedule through out their reproductive life and health care provider should play an essential role in supporting the necessary scientific knowledge about the completeness of immunization doses with regular home visits by health workers about the immunization coverage with the recommended doses of TT vaccine especially for women between the age of 15- 45 years .

\section{References}

[1]Orange JS, Ballow M, Stiehm ER, et al. Use and interpretation of diagnostic vaccination in primary immunodeficiency: a working group report of the Basic and Clinical Immunology Interest Section of the American Academy of Allergy, Asthma \& Immunology. J Allergy Clin Immunol 2012; 130.

[2]Black RE, Cousens S, Johnson HL, Lawn JE, Rudan I, Bassani DG, et al , Child Health Epidemiology Reference Group of WHO and UNICEF. Global, regional, and national causes of child mortality in 2008: a systematic analysis. Lancet, 2010; 375: 1969-1987.

[3] Khan R, Vandelaer J, Yakubu A, Raza AA, Zulu F. Maternal and neonatal tetanus elimination: from protecting women and newborns to protecting all. International Journal of Women's Health, 2015; 7: 171180.

[4]Department of health UK. Immunization against infectious disease. The green Book. 3rd ed. London ; The stationary office .Tetanus , 2009.

[5]Maral I, Baykan Z, Aksakal F, Kayikcioglu F, Bumin MA. Tetanus immunization in pregnant women: evaluation of maternal tetanus vaccination status and factors affecting rate of 
vaccination coverage. Public Health, 2001

; 115: 359-364.

[6] Survey in the Chittagong Hill Tracts. The Nielsen Company Bangladesh Limited: Dhaka, Bangladesh, $2010 ; 30-36$.

[7] Nisar N, Aziz N, Mumtaz F. Tetanus toxoid vaccination coverage among pregnant women at tertiary care hospital, Sindh Pakistan. Med Channel, 2010 ; 16: 272-27.

[8] Mohakhali D , EPI Headquarter World Health Organization (WHO). Weekly Epidemiological Record, WHO: Geneva , 2009; (20).

[9] Zeb A, Zaidi S, Jehan I. Knowledge attitude and practices of reproductive age females about tetanus toxoid vaccine: a pilot study. Journal of the College of Physicians and Surgeons - Pakistan: JCPSP , 2006 ; 16: 791-793.

[10] Park K, Epidemiology of communicable diseases .Parks text book of preventive and social medicine . 27thed . Jabalpur : Banarsidas Bhanot .2007: 260. [11]Blencowe H, Lawn J, Vandelaer J, Roper M, Cousens S. Tetanus toxoid immunization to reduce mortality from neonatal tetanus. Int $\mathbf{J}$ Epidemiol. 2010;39:102-109.

[12]The Pocket Book of Statistics. Bangladesh Bureau of Statistics (BBS): Dhaka, Bangladesh; 2009.

[13]Siddiqi N, Khan A, Nisar N, Siddiqi AE. Assessment of EPT() expanded program of immunization ) vaccine coverage in per- urban area. JPak Med Assoc , 2007; 57: 391-5.
[14]Mohammad N , Muhammad ZK, Syed H A, Muhammad A, Ayasha K, Syeda M N, Muhammad U K. Coverage and factors associated with tetanus toxiod vaccination among married women of reproductive age ( A- cross- sectional study in Peshawar ). J Ayub Med Coll Abbottabad 2010;22(3): 136- 140 .

[15] Islam MZ , Ahmed MS , Nafiza A , Farjana S , Mazumder SK. Tetanus toxoid vaccination coverage among women of reproductive age: Experience from a rural community Bangladesh Medical Journal, 2012; 41( 1): 37- 41 .

[16] Rahman MM. Determinants of the utilization of the tetanus toxoid (TT) vaccination coverage in Bangladesh: 2004. Int J Health 2009;8(2).

[17]Afridi NK, Hatcher J, Mahmud S, Nanan D. Coverage and factors associated with tetanus toxoid vaccination status among females of reproductive age in Peshawar. J Coll Physicians Surg Pak 2005;15:391-5. [18]WHO vaccinepreventable diseases: monitoring system 2010 global estimates. 10 September 2010. [19] Mohammad AB , Nahida M , Athraa KL. Assessment of vaccination status of reproductive women aged (15-45) years concerning tetanus toxiod in Al-Shatrah primary health care centers ,3d international conference of medical and health specialties , Middle Technical University , 2016: 558 . [20]Hasnain S, Sheikh NH. Causes of low tetanus toxoid vaccination coverage in pregnant women in Lahore district, Pakistan. East Mediterr Health J 2007;13:1142-52. 
[21]Inakci HI, Simsek Z, Koruk I, Koruk ST. Coverage of tetanus vaccine after national tetanus vaccination campaign and basic determinants in Sanliurfa. TAF Prev Med Bull 2009;8(6):453-8.

[22]Nisar N, Mirza M, Qadri MH. Knowledge, attitude and practices of mothers regarding immunization of one year old child at Mawatch Goth, Kemari Town, Karachi. Pakistan. J Med Sci, 2010;26(1):183-6.
[23] Khan MN, Rahman ML, Miah AA, Islam MS, Musa SA, Tofail F. Vaccination coverage survey in Dhaka District. Bangladesh Med Res Counc Bull 2009; 31(2): 46-53. 